\title{
Determinants of Demand for Foreign Tourism in Indonesia
}

\author{
\begin{tabular}{c} 
Joko Mariyono \\
Postgraduate School of Management, University of Pancasakti \\
Corresponding Author: mrjoko28@gmail.com \\
\hline
\end{tabular}
}

Recieved: June 2016; Accepted: May 2017

\begin{abstract}
This study aims to analyse the determinants of foreign tourists coming to Indonesia. Tourism sector is important in Indonesian economy because it is one of potential sources of foreign exchange and promotes economic growth. Decrease in number of domestic tourists is not as important as foreign ones since the later can be a potential source of foreign exchange. Model of travel cost demand for tourism is estimated using panel data, consisting of 34 countries across the globe during 2002-2011. Data were compiled from Indonesian Statistical Agency and the World Bank database. The result shows that distance is a one of significant factors that reduces the number of foreign tourists coming to Indonesia. The richer and larger countries boost greater amount of tourists traveling to Indonesia. Bomb attack reduced the number of foreign tourists. Tourists from western and ASEAN countries were more likely to visit Indonesia than others. Last, the trend of foreign tourists increased after significant fall because of bomb attacks. Indonesian policy should provide a guarantee of safety to tourists in order to attract more arrivals. Increase in such visit will lead to increase in job creation and share of GDP, and eventually strengthen Indonesian economy.
\end{abstract}

Keywords: tourism sector, foreign tourists, demand for tourism, travel cost model, bomb attacks.

JEL Classifications: O24, J23, R41, Z32

\section{Introduction}

Tourism is one of important sectors in the economy. The sector is a powerful tool for national economic growth and has significantly generated employment. It does not only provide an opportunity for host countries to diversify their economic sectors, but also creates new employment opportunities, especially for women, young people and disadvantaged groups. Tourism offers low skill entry for some of its labour requirements and is therefore a significant mechanism for poverty reduction (ILO, 2009).

Tourism leads economic growth. Many studies have explored and shown that development of tourism sectors has helped many countries achieve higher economic growth. A study by Othman and Salleh (2010) finds that one-way relationship exists between tourism development and economic growth. For the United Kingdom, Italy, Hong Kong and Singapore, the growth of the tourism industry contributes towards economic growth, while for the United States, Spain, Malaysia and China, the growth of the economy is the leading factor to tourism development. This is consistent to a study by Çağlayan et al. (2012) showing that there is bidirectional causality, but this findings support the comprehensive conclusion about the relationship between tourism and economic growth.

The tourism-led growth hypothesis suggests that international tourism plays an important role in economic growth. The relationship between international tourism and economic growth has been a subject of great interest and debate among economists in recent years. The debate has traditionally analysed whether expansion in tourism industry results in a faster economic growth. International tourism provides substantial economic benefits to host countries (Savaşetal.,2010). International tourism revenues 


\section{Jurnal Ekonomi Pembangunan, 18 (1), 2017, 82-92}

were the major source of foreign exchange, especially for less-developed countries confronted by foreign exchange constraints (Oh, 2005). This is consistent to evidences in Italy (Brida et al., 2010), Tunisia (Cortés-Jiménez et al., 2011) and Greek (Eeckels et al., 2012). Consequently, the findings support the tourism-led economic growth hypothesis and are of particular interest and importance to policy makers, financial analysts and investors dealing with the tourism industry

Tourism sector plays an important role in the economic development. It promotes economic growth and is considered as an invisible export because of its ability to collect foreign exchange, as well as real exports of other commodities. It has been noticed that international tourism is one of the largest industries in world and it continues to grow because of travel needs of human being (Antariksa, 2008). Tourism sector has provided contribution of US $\$ 3.3$ trillion to gross domestic product (GDP) in the planet, which is equivalent to around $11 \%$ of global GDP. It also contributed to $8 \%$ of global employment, which accounted for around 207 million of workforces in the world (Lundria, 2006). In Malaysia, the development of tourism has definitely generated local employment opportunities. A total of 938 jobs were created which included direct, indirect and induced employment (Yacob et al., 2007).

Tourism sector is important in Indonesian economy. It is one of potential sources of foreign exchange. In addition, tourism is also able to enhance income tax of the country. The sector has contributed significant share of GDP and employment. International tourism arrivals have provided contribution of tourism revenue to Indonesia's GDP. A significant growth from 2000 to 2007 , it has more than doubled from US $\$ 15.5$ billion in 2000 to almost US\$34 billion in 2007. During the years 2002, 2003 and 2006 when there were declines in foreign visitor arrivals there were year-on-year increases in the contribution of tourism revenue to GDP of $8.6 \%, 9.7 \%$ and $18.6 \%$ respectively (ILO, 2009). This could demonstrate the strength of the domestic visitor market.
Tourism generates jobs. The UN-ILO has highlighted tourism as one of significant sectors for developing and emerging countries, where it contributes to enhancing standards of living, reducing poverty and promoting respectable work. In countries where tourism sector has a major impact on foreign exchange earnings, employment creation and share of GDP, the consequences of situation that affect tourist arrivals should have significant impact on the economy (ILO, 2009).

Employment in tourism sector shows similar patterns to those for international visitor arrivals. Certainly, for the same years that there were declines in foreign arrivals, there were also drops in employment in the sector, in terms of both direct and indirect impacts. In fact for 2002 and 2006 the declines in employment were more severe. There has been a fall in total employment from 2000 to 2007 of roughly $7 \%$ (ILO, 2009).

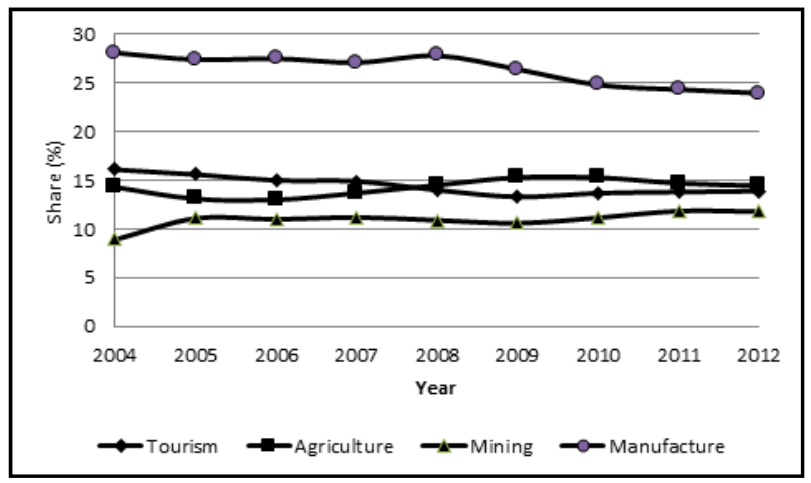

Figure 1. Share to Indonesian GDP of main sectors Source: Indonesian Statistical Agency (various years)

Compared to other sectors, contribution of tourism is three largest, together with manufacture and agriculture, as shown in Figure 1. However, during recent years the share to the Indonesian GDP tends to decrease. Many factors affect the decrease in the share. One of important factors is the number of tourist arrivals, both foreign and domestic tourists. The fact that both international and domestic tourist play an important role in the economy, but decrease in number of domestic tourists is not as important as foreign ones since the later can be potential source of foreign exchange. 


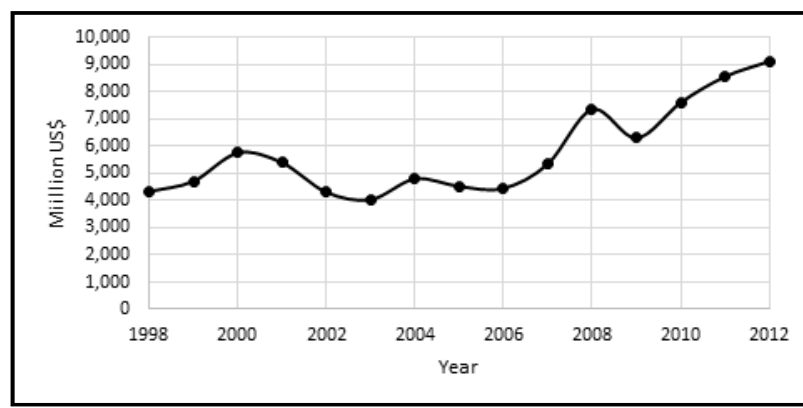

Figure 2. Trend of foreign exchange from tourism sectors

Source: Indonesian Statistical Agency (various years)

Based on the trend of foreign exchange from tourism that tends to increase (see Figure 2), one possible factor of fall in share in GDP from tourism is the decrease in domestic one. Foreign exchange in Indonesia started increasing since 2009 after ten-year fluctuations because of various factors. One of important factors relates to travel waring associated with national security.

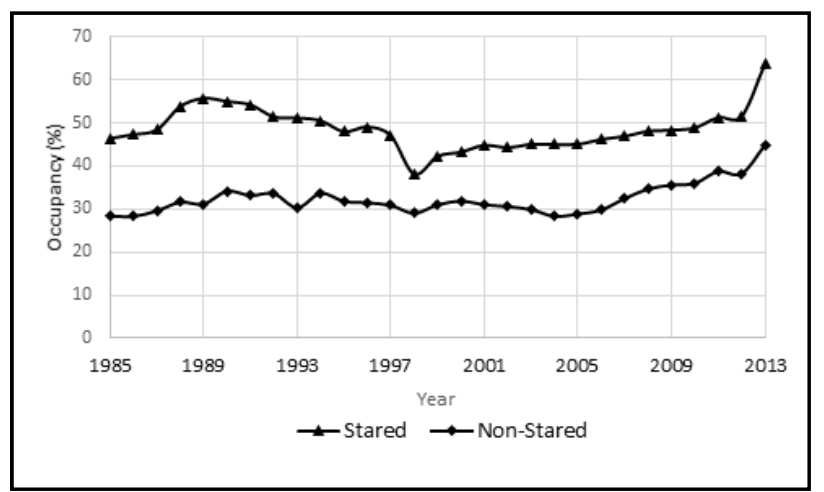

Figure 3. Trend of hotel occupancy in Indonesia Source: Indonesian Statistical Agency (various years)

The effect of decrease in number of foreign tourists also appears in the hotel occupancy rate, particularly for stared hotels. Figure 3 shows that the rate of hotel occupancy fluctuates, even tends to decrease during 1985-2005. After that, the rate increase along with the increase in number of foreign tourists. Note that rate of occupancy of stared hotel fluctuates more than that of nonstared ones.

Increasing the number of foreign tourists to Indonesia has stimulated the hospitality industry. It is indicated by the construction of hotel that continues to grow, especially budget hotel. Hospitality industry will be more vivid due to the increase in foreign tourists visiting Indonesia. It is predicted that in 2013 , the number of rooms will increase from 50,000 to 100,000 hotel rooms in Indonesia. In 2012, the number of rooms available 240,000 of 15,300 hotel rooms throughout Indonesia.

The new hotel will also be more popping up in larger cities of major tourist destinations such as Bali and Jakarta. The average hotel occupancy rate reached $70 \%$ and $90 \%$ in Jakarta and Bali respectively. In Jakarta, the higher trend is to budget hotels for foreign tourists visiting the city for business. Conversely in Bali, the higher trend is three- and five-stared hotels. Currently the construction of a new hotel has begun to spread to the districts and small islands in Indonesia.

Investment hospitality industry has the opportunity to grow rapidly in the future. Investment growth in the hospitality cannot be separated from the development of Indonesia's tourism industry as a whole. Indonesia's tourism industry has a huge opportunity to grow rapidly in the future along with the increasing interest of the both local and foreign tourists to explore the country. These opportunities should certainly be captured by entrepreneurs in the tourism industry.

Since the number of foreign tourists one of important factors, a study on the factors influencing the visit of foreign tourists to Indonesia need to be analysed. Research question of this study is what drive the international tourist arrivals in Indonesia. To answer the question, this study aims to analyse the foreign tourist arrivals to Indonesia, using simple mode of travel cost approach. Particular attention was paid to the bomb attacks related to terrorism.

\section{Literature Review}

There are many literatures on modeling tourism demand focusing either on analysis of the effects of the various determinants or on the 
accurate forecasting of tourism demand. Recently, econometric techniques have also played an important role in the understanding of tourists' behavior and their demand for tourism services.

A number of empirical studies on international tourism demand are found in the literatures and in general they are divided into two main categories. The first category consists of studies that estimate the determinants of international tourism demand using classical multivariate regressions (e.g. Lim, 1999; Crouch, 1994; and Witt and Witt 1995). The second one includes studies that employ time series and co-integration techniques (e.g. Ouerfelli, 2008; Kulendran and Drivisekera, 2007; Dritsakis, 2004; Narayan, 2004; Song and witt, 2003; and Kulendran and Witt, 2001).

There are various indicators used in the study of tourism. The most of the existing empirical studies have used tourist arrivals-departures (Ouerfelli, 2008; Mervar, 2007; Dritsakis, 2004) and tourism expenditures as dependent variables (Hanly and Wade, 2007; Algieri, 2006). The number of overnight stays and the average length of stay have also been studied, but much less often (Athanasopoulos and Hyndman, 2007; Muñoz, 2007).

There are a number of studies focusing on tourism demand. For example, Algieri (2006) used the vector auto regression model to examine the determinants of tourism receipts in Russia, and the results show that the significant longrun co-integration relationship between Russian tourism receipts, real exchange rates, world GDP and air transport prices. Song and Witt (2003) studied the tourism demand to Thailand from seven major countries using the autoregressive distributed lag (ARDL) model. Their studies found that the terrorist attack of 11 September 2001, the Iraq war, and the SARS epidemic in 2003, were significant effects on international tourism demand to Thailand. Dritsakis (2004) using error correction model found that the longrun relationship among important economic variables determining German and United
Kingdom tourism demand to Greece. Kulendran and Drivisekera (2007) examined the effects of marketing expenditure on tourism demand for Australia using the ARDL model, and the results show that both the 'word-of-mouth effect' and visitor's satisfaction arrives to repeat visits also play an important role in promoting international tourist arrivals to Australia. Han et al. (2006) used an almost ideal demand system model to investigate the US tourism demand for several European countries and they found an increase in prices in France results in an increase in US tourists' demand for Italy, indicating that France and Italy was considered substitutable by US visitors. Ouerfelli (2008) used the error correction models to estimate the long-run tourism demand elasticities from the several European countries to Tunisia. The result shows that the relative prices and the income are highly elastic; also supply factor is significant in the destination choice decision especially for French and Italian tourists. Wang (2009) investigated tourism demand from Japan to Taiwan using ARDL model and the result indicates that the coefficient of transportation cost variables are statistically significant and negative sign, indicating that an increase in oil prices result to decrease Japanese tourist arrivals to Taiwan. The study also shows that the number of tourist arrivals declined the most during the disease outbreak, followed by the earthquake on September 21 and the terrorist attack September 11. The impact of the Asian financial crisis was relatively mild.

On reviewing the literatures, one finds that there exist a few of empirical studies that have analyzed tourism demand for Malaysia using both the traditional and modern econometric techniques. Anaman and Ismail (2002) analyzing the tourism demand from Brunei to Eastern Malaysia indicated that the main factors including personal income, exchange rate, the availability of lower price and better quality of goods and services in Malaysia relatively to Brunei are the driving force of tourist coming to Malaysia. Tan et al. (2002) examined the determinants of tourist 


\section{Jurnal Ekonomi Pembangunan, 18 (1), 2017, 82-92}

coming to Malaysia and Indonesia. They found that the income per capita is an important factor that influences the decisions of tourists to travel to Indonesia and Malaysia. Salleh et al. (2007) investigated the tourism demand to Malaysia from 10 major markets, and results show that the world of mouth has a positive relationship in long-run, the 1997 economic crisis and the outbreak of SARS have a negative relationship in the short-run. Lean and Smyth (2008) examined the converging tourist arrivals from ten major markets. The result demonstrates that the visitor arrivals from ten markets are converging with total tourist arrivals, and marketing strategies targeted at these markets are effective.

So far, number of studies on tourist arrivals to Indonesia is still limited. There is a study by Pratomo (2003) specifically examining tourist arrivals to Indonesia using economic exogenous variables, and the result normatively indicates that economic factors played important roles in attracting foreign tourists coming to Indonesia. One crucial lack in the most studies in estimating tourist arrivals is the absence of distance of country origin to Indonesia. This is an important variable since tourism is non-market value the distance could be considered a shadow price of tourism. Thus, estimating the demand for tourism without the distance has a potential bias specification. With current development in national security, it is also important to investigate the effect of bomb attacks on the tourist arrivals. This study use travel cost model (TCM) to estimate demand for international tourism in Indonesia.

\section{Methodology}

A travel cost model is used in this analysis. Several issues related to this model remain less than satisfactorily resolved, but the acceptability of the TCM is increasing (Ward and Loomis, 1986). The model uses data on costs incurred by visitors travelling to a tourism site to infer their willingness to pay for the recreation facilities that the site offers. This enables estimation of the demand curve for recreation at the park and therefore provides an estimate of the recreational value of the park (Lansdell and Gangadharan, 2001). This approach postulates that cost of travel is used as a proxy of tourism price. The further destination of travel represents the more expensive tourism site. The model of demand for tourism is formulated as a linear functional form to make it easy to interpret. The linear functional form of demand for tourism is formulated as:

TOUR $=\beta_{0}+\beta_{1} D I S+\beta_{2} G D P C+\beta_{3} P O P+\beta_{4} E X R+$ $\beta_{5} B O M+\beta_{6} A S E+\beta_{7} W E S T+\beta_{8} T+\beta_{9} T 2+\varepsilon$

where TOUR is the number of foreign tourists coming to Indonesia, DIS is distance between capital city of Indonesia to capital cities of visitor countries, GDPC is gross domestic product per capita of visitor countries, $P O P$ is population of visitor countries, $E X R$ is exchange rate of US\$ to IDR, BOM is dummy for bomb attacks in 2003 and 2005, $A S E$ is dummy variable for ASEANmembers, WEST is dummy variable for western countries, $T$ is time trend, is error term, and $B$ is coefficient regression to be estimated. $B O M$ is the variable of interest because it is an internal factor that can be controlled by Indonesian government. It is an indicator representing national security that guarantees the safety of visitors. Other variables are external factors to Indonesia and these are beyond government control.

The relative impact of each factor on tourism was measured using mean elasticity of demand. The mean elasticity of demand for tourism was calculated at average level of each factor, which was defined as:

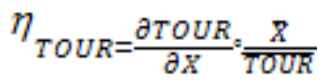

where is average value of factor affecting tourism.

Model of travel cost demand for tourism is estimated using panel data, consisting of 34 countries across the globe during ten-year periods of 2002-2011. Data were compiled from Indonesian Statistical Agency and the World Bank database. 


\section{Jurnal Ekonomi Pembangunan, 18 (1), 2017, 82-92}

This study pay close attention to a particular issue, namely bomb attacks. Variables included in the analysis are: distance measuring cost of travel, gross domestic product (GDP) per capita measuring the richness of foreigners, population measuring the size of country origin, exchange rate measuring relative strength of foreign currency, bomb attacks and cultures.

Table 1. Summary statistics of data

\begin{tabular}{lccccc}
\hline \multicolumn{1}{c}{ Variable } & Obs & Mean & Std. Dev. & Min & Max \\
\hline Tourist arrivals & 340 & 157342.9 & 294453 & 4579 & 1644717 \\
Distance (miles) & 340 & 7577.3 & 4006 & 906 & 14978 \\
GDP/Cap (\$-PPP) & 340 & 24178.4 & 15030 & 1028 & 53591 \\
Population (million) & 340 & 140.3 & 289 & 0.3416 & 1344.13 \\
Exchange rate (US\$-IDR) & 340 & 9324.6 & 507 & 8616 & 10450 \\
Bomb attacks (dummy) & 340 & 0.20 & 0.40 & 0 & 1 \\
ASEAN (dummy) & 340 & 0.18 & 0.38 & 0 & 1 \\
Western (dummy) & 340 & 0.50 & 0.50 & 0 & 1 \\
\hline
\end{tabular}

Table 1 summarizes the data used in this study. Standard deviation shows variation in such data; and this is expected to provide enough power in estimating the proposed demand function for tourism to Indonesia. Panel regression model with random effect is employed to fit the nature of data available. Robust standard error is adopted to cope with possibility of problem of strong heteroschedasticity (Verbeek, 2002).

\section{Result and Discussion}

Let us first discuss the trend of foreign tourists visiting Indonesia during 2002-2011 shown in the Figure 4. In general, we can see that the tourism increased steadily. The 2003bomb attack in Bali caused significant fall in number of tourists coming to Indonesia. But it quickly recovered because of the Indonesian government provide guarantee and commitment to eradicate terrorism. The fact that terrorists were arrested and given death penalty showed that the government has seriously eradicated the terrorism. In 2004, the number of tourists was greater than that in 2002 .

However, bomb attacked in 2005, and this also reduced the number of tourists. The impact of second bomb was more persistent than that of previous one, as indicated that the recovery of tourism was quite slow. Three years after the second bomb attack, there was significant increase in number of tourists, along with the actions of government in arresting terrorists. This also relates to an effort conducted by the Ministry of Culture and Tourism that pursued the Visit Indonesia 2008 program and a series of tourism events to attract foreign visitors to Indonesia. In Malaysia, a study shows that global economic crisis during 1997-98 and the outbreak of SARS in 2002-2003 significantly affected the demand for Malaysia's tourism (Salleh et al., 2008). Improvement awareness and build collaborative links with other Asian destinations was thought to help in boosting foreign arrivals, including for business purposes from Asian countries.

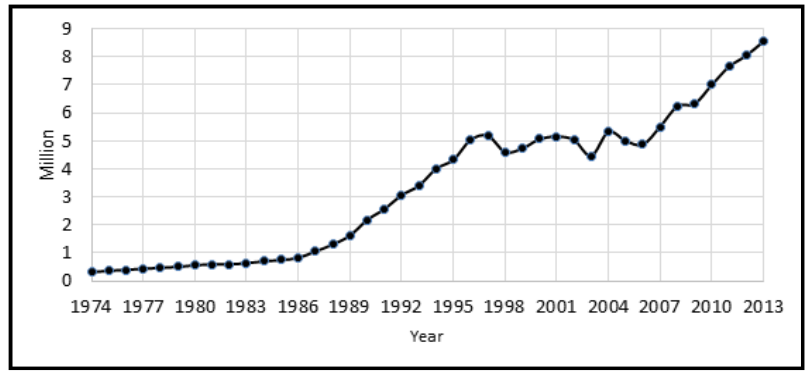

Figure 4. Trend of foreign tourism to Indonesia Source: Indonesian Statistical Agency (various years)

Table 2 shows the estimated demand for tourism of foreigners to Indonesia. Overall, the demand is significant, which is shown by the 


\section{Jurnal Ekonomi Pembangunan, 18 (1), 2017, 82-92}

value of Wald test. We can see that coefficient determination is quite low, which accounts for only $34 \%$. This means that many other factors beyond this analysis have determine the number of foreign tourist visiting Indonesia. These factors include socio-economic-political aspects of countries, climate and travel warnings from both country origins and Indonesia. Indonesia has suffered political and economic instabilities that continue to have severe negative impacts on international tourist arrivals to the country. Unpredictable events such as this remain beyond the control of local or national stakeholders, and although tourism was not the only industry to have been affected by the instabilities (Walpole and Goodwin, 2000).

Table 2. Estimated demand for tourism to Indonesia

\begin{tabular}{ccccc}
\hline Variables & Coef. & se & $\mathbf{z}$ & $\mathbf{p}>\mathbf{z}$ \\
\hline CONSTANT & 127659 & 140865 & 0.91 & 0.365 \\
DISTANCE & -34.3 & 15.86 & -2.17 & 0.030 \\
GDP/CAP & 6.24 & 3.35 & 1.86 & 0.062 \\
POPULATION & 251.8 & 109.98 & 2.29 & 0.022 \\
EXC-RATE & 1.82 & 4.94067 & 0.37 & 0.713 \\
BOMBS & -13981 & 5485 & -2.55 & 0.011 \\
ASEAN & 204607 & 197594 & 1.04 & 0.300 \\
WESTERN & 99543 & 106041 & 0.94 & 0.348 \\
T & -10022 & 5628 & -1.78 & 0.075 \\
T2 & 1487 & 548 & 2.72 & 0.007 \\
R & within & $=$ & 0.1439 & \\
& between & $=$ & 0.3429 & \\
& overall & $=$ & 0.3371 & \\
Wald & $\chi 2 N o .9)$ & $=$ & 22.69 & \\
Prob & $>\chi 2$ & $=$ & 0.0069 & \\
\hline
\end{tabular}

Note that global economic crisis was likely to affect the foreign tourist arrivals. It should be remembered that the avian influenza pandemic, political tensions and natural disasters were also factors for the Asia Pacific regions, including Indonesia. For instance, a study by Salleh et al. (2007) indicates that the 1997-98 East Asian economic crisis and the epidemic of severe acute respiratory syndrome (SARS) significantly affected Malaysia's tourism demand. In Taiwan, it has been proven that avian-flu has been reducing number of international tourism (Kuo et al., 2009). In the case of Indonesia, the country has also been suffered from a series of natural disasters in the last three years, which were thought to have greater impacts on tourism than the global economic crisis. However, important factors analysed here can provide important information.

The analysis shows that distance is a one of significant factors that reduces the number of foreign tourists coming to Indonesia. ${ }^{1}$ This is understandable because further away country origins to Indonesia are more costly. GDP per capita, which represent richness of country origins, has significant positive impact on foreign tourist arrivals. This also makes sense, since tourism is a kind of normal goods, in which there is an increase in demand for tourism when income increases. The richer and larger countries boosted greater amount of tourist arrivals. In this case, bomb attack really reduced the number of foreign

1 The effect distance was linear. Testing for non-linear effect using quadratic form did not show significant effect. 


\section{Jurnal Ekonomi Pembangunan, 18 (1), 2017, 82-92}

tourists. Exchange rate has expected impact, that is, the number of tourists increased when the Indonesian currency was depreciated against US $\$$, but it is not significant. A study using econometric models by Lumaksono et al. (2012) identifies the variables which influence tourists both the number of arrival/departure and their average expenditure per visit. GDP was the most influencing variable as well as exchange rate that give higher impact compared to the other variables.

As expected, tourists from western and ASEAN countries tend to visit more to Indonesia. In Western culture, it is well known that tourism is one of routine agendas, particularly during holydays. Tourists from ASEAN countries have a special facility, that is, no need to apply visa for visit to ASEAN member countries. Last, the trend of foreign tourists increased after significant fall because of bomb attacks.

Table 3. Mean demand elasticity

\begin{tabular}{lc}
\hline \multicolumn{1}{c}{ Factor } & Elasticity \\
\hline DISTANCE & -1.6538 \\
GDP/CAP & 0.9593 \\
POPULATION & 0.2246 \\
EXC-RATE & 0.1076 \\
\hline
\end{tabular}

Table 3 shows mean-elasticity of demand for tourism with respect selected factors. In absolute value, distance has the highest magnitude, which indicates that an increase in distance by $1 \%$ leads to a decrease in tourist arrivals by $1.65 \%$. This implies that tourism promotion to neighbouring countries of Indonesia is expected to have higher impact than that to further country origins, such as African and American countries. High elasticity is also shown by GDP per capita of country origins, which almost unitary elastic demand for tourism, at which an increase in GDP per capita by $1 \%$ in the country origins leads to a rise in tourist arrivals by $1 \%$. There is a positive hope that global economic crisis recovery is expected to increase tourist arrivals to Indonesia. Positive elasticity with respect to population means that tourist arrivals will is also expected to increase along with world population growth, conditional to positive global economic growth. Indonesia needs to anticipate the positive external factors by preparing tourist national destinations more attractive and competitive than other tourist destinations of neighbouring countries.

As the prevailing perception amongst tourism professionals that Indonesia's tourism marketing campaign is still weak and in particular underperforming it's potential -in relation to what the country has to offer- it is strongly recommended that Indonesia promotes tourism to neighbouring countries as intensively as that conducted by Thailand's and Malaysia's marketing campaigns. Tourism collaboration among ASEAN members and other countries in Pacific regions is expected to improve regional economic development.

One strategy that can be executed is the digital marketing. To execute this strategy, the ability of digital marketing communication needs to be built in order to win the current competitive tourism industry, considering the neighbouring countries are very aggressive in selling remarkable destinations. The Indonesian tourism industry should be able to master digital technology-based marketing communications. Because, according to the survey, about $65 \%$ of tourists are looking for ideas travel through social media. For example, about $50 \%$ of Facebook users are influenced by photographs of friends in their Facebook network to determine the tourist attractions, $33 \%$ of tourists to change their original plans after seeing these photos. Thus, the Indonesian tourism industry should be able to build a reputation in social media, engaging the user in order for them to come to the destination of Indonesia. The more visitors that come the need for a place of accommodation or hotel is also higher, and certainly there will be more new jobs created.

In the long run, innovation on tourism in Indonesia needs to be built. Albaladejo and Martínez-García (2015) pointed out that 


\section{Jurnal Ekonomi Pembangunan, 18 (1), 2017, 82-92}

research and development on tourism has a positive impact on economic growth as innovation is the motor of carrying capacity growth. There is no significant innovation on tourism has been built in Indonesia. So far, Indonesia still enjoys the exotic island's natural and cultural resources to attract foreign visitors. This is one of economic growth sources. However, this condition will reach the carrying capacity growth at certain point of time.

\section{Conclusion and Policy Implication}

Tourism sector, particularly international visitors, is a potential source of foreign exchange and generates significant employment in Indonesia. Many evidences show that the sector has been an engine of economic growth. Reduction in number of foreign tourist arrivals could reduce employment, in terms of direct and indirect mechanism. Despite the fact that foreign tourist arrivals to Indonesia tends to increase, there is internal factor that make the arrivals dropped, particularly related to safety issues. Bomb attacks have the culprit of such decline in the number of tourist arrivals. As there is a hope that recovery of global economic crisis, particularly in western countries, the numbers of tourist arrivals is expected to increase significantly. Based on the analysis, Indonesian policy should provide a guarantee of safety to foreign tourists in order to attract more tourists travelling to Indonesia. The promotion event, such as the Visit Indonesian Year (VIY), is essential in encouraging the international tourists to travel to Indonesia. In fact, the VIY is a starting point of the development of tourism industry in Indonesia. Therefore, if the big promotion event as the VIY will be held again in the future, it is essential to ensure better management, promotion policy, and pricing policy because of the high competitiveness, especially among ASEAN countries. Finally, for the future research, relative consumer price index (CPI) is one variable that is essential as a proxy to show the effect of relative price to demand for tourism. Unfortunately, Indonesia still lacks of appropriate data to show that good proxy, such as CPI for hospitality industry or entertainment industry. Therefore, it will be useful if there is an accurate measurement of those variables collected by government of Indonesia, especially by Ministry of Tourism and Culture. Increase in such visit will lead to increase in share of GDP, creating employment and strengthen Indonesian economy. This may be useful for local authorities involved in the development of tourism, and represent a starting point for further research dealing with future trends.

\section{Acknowledgment}

The authors thank research assistants who provided helps in data collection. The authors are responsible for interpretation and errors.

\section{References}

Albaladejo, I.P.; Martínez-García, M.P. (2015). "Endogenous economic growth; market equilibrium; open economy; tourism; tourists' preferences", Tourism Economics, Vol. 21, No. 4, pp. 701-719.

Algieri, B. (2006). "An econometric estimation of the demand for tourism: the case of Russia", Tourism Economics, Vol. 12 No. 1, pp. 5-20.

Anaman, A.K., and Ismail, A.R. (2002). "Crossborder tourism from Brunei Darussalam to Eastern Malaysia: An empirical analysis", The Singapore Economic Review, Vol. 47 No. 1, pp. 65-87.

Antariksa, B. (2008), “Tinjuan terhadap kebijakan penanaman modal asing dan pembangunan kepariwisataan Indonesia", Jurnal Kepariwisataan Indonesia, Vol. 3 No. 2, pp. 195-214.

Athanasopoulos, G., and Hyndman, J. R. (2008). "Modeling and forecasting Australian domestic tourism", Tourism Management, Vo. 29 No. 1, pp. 19-31.

Brida, J.G., Barquet, A., and Risso, Wiston, A. (2010), "Causality between economic growth 


\section{Jurnal Ekonomi Pembangunan, 18 (1), 2017, 82-92}

and tourism expansion: empirical evidence from Trentino-Alto Adige", Tourismos: An International Multidisciplinary Journal of Tourism, Vol. 5 No. 2, pp. 87-98.

Çağlayan, E., Şak, N., Karymshakov, K. (2012), "Relationship between tourism and economic growth: a panel granger causality approach", Asian Economic and Financial Review, Vol. 2 No. 5, pp. 591-602.

Cortés-Jiménez, I., Nowak, J-J., and Sahli, M. (2011), "Mass beach tourism and economic growth: lessons from Tunisia", Tourism Economics, Vol. 17 No. 3, pp. 531-547.

Crouch, G. (1994). "The study of international tourism demand: a review of findings", Journal of Travel Research, Vol. 3 No. 1, pp. 12-23.

Dritsakis, N. (2004). "Cointegration analysis of German and British tourism demand for Greece", Tourism Management, Vol. 25 No. 1, pp. 111-119.

Eeckels, B., Filis, G., and Leon, C. (2012), "Tourism income and economic growth in Greece: empirical evidence from their cyclical components", Tourism Economics, Vol. 18 No. 4, pp. 817-834.

Han, Z., Durbarry, R., and Sinclair, M.T. (2006). "Modelling US tourism demand for European destinations", Tourism Management, Vol. 27 No. 1, pp. 1-10.

Hanly, P. and Wade, G. (2007). "Modeling tourism demand an econometric analysis of North American tourist expenditure in Ireland,1985-2004", Tourism Economics, Vol. 13 No. 2, pp. 319-327.

ILO (2009), Implications of the Global Economic Crisis for Tourism Employment: Case Study for Indonesia. International Labour Organization 2009. Jakarta Office; ILO,
2009

Kulendran, N., and Divisekera, S. (2007). "Measuring the economic impact of Australian tourism marketing expenditure", Tourism Economics, Vol. 13 No. 2, pp. 261274.

Kulendran, N., and Witt, S. (2001). "Cointegration versus least squares regression", Annals of Tourism Research, Vol. 28, No. 2, pp. 291311.

Kulendran, N., and Witt, S. F. (2003). "Leading indicator tourism forecasts", Tourism Management, Vol.24 No. 5, pp. 503-510.

Kuo, H.-I., Chang, C.-L. Huang, B.-W., Chen C.C. and McAleer, M. (2009), "Avian flu and international tourism demand: A panel data analysis", available at:http://www. mssanz.org.au/MODSIM07/papers/32_s22/ AvianFlu_s22_Kuo_.pdf (accessed 28 March 2012)

Lansdell, N. and Gangadharan, L. (2001), "Comparing travel cost models and the precision of their consumer surplus estimates: Albert Park and Maroondah reservoir", The University of Melbourne Department of Economics, research paper no. 796 June 2001.

Lean, H. H., and Smyth, R. (2008). “Are Malaysia's tourism markets converging? Evidence from univariate and panel unit root tests with structural breaks". Tourism Economics, Vol. 14 No. 1, pp. 97-112.

Lim, C. (1999). "A meta-analytical of international tourism demand", Journal of Travel Research, Vol. 37 No. 3, pp. 273-284.

Lumaksono, A., Priyarsono, D.S., Kuntjoro, K and Heriawan, R. (2012), "Dampak ekonomi pariwisata internasional pada perekonomian Indonesia", Forum Pascasarjana, Vol. 35 No. 1, pp. 53-68. 


\section{Jurnal Ekonomi Pembangunan, 18 (1), 2017, 82-92}

Lundria, I. (2006), "Pariwisata Indonesia dan pembangunan berkelanjutan", Jurnal Bisnis \& Birokrasi, Vol. 14 No. 2, pp. 471-479.

Mervar A. and Payne, J.E. (2007). "Analysis of foreign tourism demand for Croatian destination: long-run elasticity estimates", Tourism Economics, No. 3 Vo. 13, pp. 407420.

Muñoz, T.G. (2007). "German demand for tourism in Spain”, Tourism Management, Vol. 28, pp. 12-22.

Narayan, P.K. (2004). "Fiji's tourism demand: the ARDL approach to cointegration", Tourism Economics, Vol. 10 No. 2, , pp.193-206.

Oh, C. (2005), "The contribution of tourism development to economic growth in the Korean economy", Tourism Management, Vol. 26 No. 1, pp. 39-44.

Othman, R. and Salleh, N.H.M. (2010), "Analisis hubungan pembangunan industri pelancongan dan pertumbuhan ekonomi: perbandingan pasaran antara bangsa", Jurnal Ekonomy Malaysia, Vol. 44 No. 2010, pp. 93-100.

Ouerfelli, C. (2008). "Co-integration analysis of quarterly European tourism demand in Tunisia”, Tourism Management, Vol. 29 No. 1, pp. 127-137.

Pratomo, D.S. (2003). "Determinants of international demand for tourism to Indonesia", TEMA, Vol. 4 No. 2, pp. 154-167.

Salleh, N.H.M., Othman, R., and Ramachandran, S. (2007), "Malaysia's tourism demand from selected countries: The ARDL approach to cointegration", International Journal of Economics and Management, Vol. 1 No. 3, pp. 345-363.

Salleh, N.H.M., Siong-Hook, L., Ramachandran, S., Shuib, A., and Noor, Z.M. (2008), "Asian tourism demand for Malaysia: a bound test approach", Contemporary Management
Research, Vol. 4 No. 4, pp. 351-368.

Savaş, B., Beşkaya, A., and Şamiloğlu, F. (2010), "Analyzing the impact of international tourism on economic growth in Turkey", ZKU Journal of Social Sciences, Vol. 6 No. 12, pp. 121-136.

Song, H., Witt, S.F., and Li, G. (2003). "Modelling and forecasting the demand for Thai tourism", Tourism Economics, Vol. 9 No. 4, pp. 363-388.

Tan, Y. F., McCahon, C., and Miller, J. (2002). "Modelling tourist flows to Indonesia and Malaysia", Journal of Travel and Tourism Marketing, Vol. 12 No. 1-2, pp. 63-84.

Verbeek, M. 2002. A Guide to Modern Econometrics. Chichester: John Wiley \& Sosn, Ldt.

Walpole, M.J., and Goodwin, H.J. (2000), "Local economic impacts of dragon tourism in Indonesia", Annals of Tourism Research, Vol. 27 No. 3, pp. 559-576.

Wang, Y. (2009). "The impact of crisis events and macroeconomic activity on Taiwan's international inbound tourism demand". Tourism Management, Vol. 30 No.1, pp. 7582

Ward, F.A., and Loomis, J.B. (1986), "The travel cost demand model as an environmental policy assessment tool: A review of literature", Western Journal of Agricultural Economics, Vol. 11 No. 2, pp. 164-178.

Witt, S.F., \& Witt, C.A. (1995). "Forecasting tourism demand: A review of empirical research", International Journal of Forecasting, Vol. 11 No. 3, pp. 447-475.

Yacob, M.R., Shuib, A., Mamat, M.F., and Radam, A. (2007), "Local economic benefits of ecotourism development in Malaysia: the case of Redang island Marine Park", International Journal of Economics and Management, Vol. 1 No. 3, pp. 365-386. 